\title{
Lost in Transnation: Taiye Selasi's Ghana Must Go
}

"We were immigrants. Immigrants leave" (Selasi, Ghana 316). Fola Sai, the main female character in Taiye Selasi's recent novel Ghana Must Go, uses these words to justify the frequent relocations of her family. In an imagined conversation with Kweku, her recently deceased ex-husband, Fola explains Kweku's abandonment of the family some sixteen years earlier by pointing to their shared past as immigrants. The novel traces the Sai family's geographical relocations between Nigeria, Ghana, the United States, and back to Ghana. They live up to what Paul White calls the essence of migration as being "about dislocation and the potential alienation of the individual from both old norms and new contexts" (6). The old norms and new contexts of home, family, nation, original culture, and language have to be re-negotiated. Regardless of whether their movements are voluntary acts of immigration, involuntary acts of forced exile, or other kinds of abandonment, all of them affect this successful African immigrant family and their four US-born children: Olu, the eldest, the twins Taiwo and Kehinde, and their younger sister Sadie.

The plot revolves around movement, both between nations in terms of geography and between families in terms of losing, leaving, searching for, and finding homes. I agree with Ketu Katrak's argument in "Colonialism, Imperialism, and Imagined Homes," when she writes that the "journeyings as exiles and expatriates" of postcolonial peoples lead to the phenomenon of "having too many roots, too many locations" (649). In Migrancy, Culture, Identity, Iain Chambers writes about the arrangements migrants have to make: “To come from elsewhere, from 'there' and 'here,' and hence to be simultaneously 'inside' and 'outside' the situation at hand, is to live at the intersections of histories and memories, experiencing both their preliminary dispersal and their subsequent translation into new, more extensive, arrangements along emerging routes" (6). Ghana Must Go is about these arrangements caused by migration. This thematic focus raises questions and challenges notions of biography and plot. First of all, the novel was written by a writer who positions herself as an Afropolitan, who includes a number of autobiographical elements in the plot, and who provides some guidelines about how to read the novel by mixing story and discourse. And second, as I will show, Ghana Must Go is an existentialist examination of a family's attempt to become and remain a family and to build up and live in a home of their own. Roots and routes merge in a search for home that, once it is found as a physical place or established as the center of a family, does not hold or provide a cheering sense of identity. This search for home concerns Fola, the displaced person who never overcomes the traumatic events of her past; Kweku, who receives education, acquires wealth, and builds up a family against all odds only to lose them again along with his dignity; Olu, the eldest son, who cannot establish emotional ties after the family is abandoned by 
the father; Taiwo and Kehinde, the brilliant and gifted twins, who are traumatized by a lack of safety and abusive treatment; and Sadie, the youngest daughter, who grows up in a disrupted family and experiences the trip back to Africa as healing.

In 2013, Ghana Must Go was published as "one of the most eagerly anticipated debut novels of the year" (Cohen). Selasi sees herself as an Afropolitan, a member of a group of highly-educated and successful people with origins in Africa who are "not citizens, but Africans, of the world" ("Bye-Bye" 528) and who re-define home as the shifting place where "[t]heir parents are from; where they went to school; where they see old friends; where they live (or live this year)" (528). Selasi sees this generation of Africans as "lost in transnation" because they have to negotiate their identities along national, racial, and cultural tensions (530). In “Bye-Bye Barbar," Selasi promotes an Afropolitan upper-class lifestyle that is shaped by her own background as a twin and as the daughter of a successful pediatrician mother who was born in Nigeria and left London to raise her twin daughters in Boston, where they attended good schools and achieved high grades. Her mother and US stepfather divorced when the twins were eight, and Taiye met her real Ghanaian father when she was twelve. At that time, her father, a surgeon, lived in Saudi Arabia, and was married to a Portuguese woman, who later remarried and lived in India. When she met her biological father at Heathrow, Selasi tells the interviewer of the London Evening Standard, she remembers scanning every African-looking man in the crowd for a possible likeness. She was disappointed when they finally met and did not feel any closeness. Selasi then talks about the visit to Accra for her father's 70th birthday and about how she found a way to reconcile with him ("Family Matters"). When she joins a family reunion with her father, his ex-wife, and her five London-born nieces and nephews, and the ex-wife's new husband in Delhi, India, Selasi remembers that they became a family despite the sense of "strange-ness" between them. "We had space in our hearts to love each other, space left vacant by previous departures, some inborn sense of how to build a family from 'found' love" ("Family Matters"). This meeting of an "extended-blendedbroken-mended family" inspired her to write the first one hundred pages of the novel.

This interview and a similar one in which she talks about growing up with an over-achieving mother, whom she calls a "panther mom" (Cohen), provide the autobiographical context for the core thematic elements of the novel: the lives of the twins, the divorces, the fathers leaving their families, the successful children of immigrant African families, the family-reunion, the migrations between Africa, Europe, and the United States. As a highly educated woman, Selasi is aware of the potential of her family background to make a larger argument about migration. She positions herself as a glamorous Afropolitan on talk shows and in the highly artistic photographic representations on her website.

Yogita Gogol contextualizes the concept of Afropolitanism by naming the large group of recent writers emerging out of Africa (with a focus on Chimamanda Ngozi Adichie's novel Americanah). Gogol sees Selasi's Afropolitanism "as a rootless, mobile identity, both linked to Africa and able to detach from stereotypical notions of the 
continent as a possible locus of critique" (xv). Gogol utters the worry that Afropolitanism "proffers elite identity as a kind of cultural capital, style without substance, commodifying a newly exotic cosmopolitan identity as a claim of difference that cannot be sustained" (xv). Selasi, who currently lives in Rome, definitely styles herself as a glamorous and articulate spokesperson of a decidedly modern Africa. Her characters possess some of the same attributes: high achievement in education (all of the characters in Ghana Must Go), an artist's international fame (Kehinde), and conspicuous professions (Olu, for example, is a surgeon). Selasi and her protagonists possess a high amount of cultural capital, but it comes at a high cost, as my reading of the novel will show, and Gogol is right in pointing out that this kind of cosmopolitan identity sometimes leads to "style without substance."

In terms that we are familiar with from structuralist linguistics, there is story and discourse. As Madan Sarup reminds us: "The story is the content, or the chain of events. The story is the 'what' in a narrative, the discourse is the 'how.' The discourse is rather like a plot, how the reader becomes aware of what happened, the order of the appearance of the events" (17). Selasi's discourse about migration comes in text passages in the novel where the narrative voice moves from mirroring the perspective of one of the family members into that of a more general voice writing and theorizing about migration. Selasi not only tells a story but also uses terms and concepts form the wide field of immigration/migration studies. ${ }^{64}$ The twins Taiwo and Kehinde share a cab on their drive from the airport to their mother's house in Accra where they gather to attend their father's funeral. When the cab driver shouts at some beggars holding up the car for money, Kehinde is embarrassed and gives them money, more than they even take. The cab driver calls the beggars thieves and concludes that Taiwo and Kehinde are tourists. When Kehinde defends himself, indignantly saying that they are not tourists, the driver only laughs at them. In most immigrant fiction where the migrant or his/her children return back to where the family originally came from, there is a similar scene of ridicule, of not belonging, of disappointment. The driver turns away when Kehinde and Taiwo cannot even tell him where their father's home was in Ghana. Of course, this scene is necessary to show character development and foreshadow later tensions. The rhetoric of using the concept of tourists, emigrants, and exiles points to a meta-level of analysis that highlights the hybridity inherent in the genre of immigrant fiction. Ghana Must Go is both a very personal and partly auto-

64 See Heike Paul on the differences and similarities between the concepts of strangers, pilgrims, tourists, nomads, and migrants (Mapping Migration, 1-33); Ruth Mayer on the concepts of postcolonialism, transculturation, and transnationalism; Rosi Braidotti for nomadic theory; Madan Sarup for concepts of identity, postmodernism, home, journey, and border; Elleke Boehmer for migrant metaphors; and the volume edited by Amritjit Singh and Peter Schmidt for postcolonial theory, race, and ethnicity. See also Cowart's Trailing Clouds for a discussion of immigrant fiction in contemporary America. 
biographical novel about a family's migration, and it is also a partly didactic lesson about what this migration means in historical and contemporary contexts.

Selasi names Toni Morrison and Salman Rushdie as her literary models. A reader who is familiar with these writers will easily trace ideas and phrases that they share. Katrak characterizes Rushdie's novels as “transnational” because they "carry modernist and postmodernist echoes, playing with levels of fantasy and reality, fragmenting history, dis-placing so-called significant events in history by presenting various contesting versions" (660). All of this applies to Ghana Must Go as well. Rushdie, Katrak writes, explores the "threads of identities-what happens to human beings when they are transported, transplanted, by choice or otherwise, into alien environments" (660). While this is an adequate description of the main thematic focus of Selasi's novel, it is also the link to Toni Morrison, a writer who is equally interested in fragments, echoes, transplantations, and threads of identities. When Fola, for example, thinks about the death of her father, she muses in a fashion reminiscent of Rushdie: "If one could die identityless, estranged from all context, then one could live estranged from all context as well” (107). Kweku, to cite an intertextual reference to Morrison's Beloved, thinks about the many things gone wrong in his life and, when he realizes he is having a heart attack, slides into "reverie, remembrance and re-other things (regret, remorse, resentment, reassessment)" (21).

In the climactic scene on the beach when Taiwo finally reconciles with her father, there is a description of a dilapidated house, a former "colonial" structure (272) that reminds Taiwo of the family's Brookline house "conceived by the same pink-faced British who would have erected this thing on this beach, hulking, rock, a declaration" (273). She imagines her father as a boy looking at this house on the beach and wanting one himself but never quite succeeding: "He conquered new land and he founded a house, but his shame was too great and his conquest was sold" (273). Taiwo understands now that her father felt shame when he left the family after he had been dismissed from the hospital where he worked as a surgeon. Again, this scene makes sense in terms of plot development, but the language is reminiscent of discussions of postcolonialism and leads to a break between what can legitimately be seen as the perspective of the character and the more knowledgeable voice behind it. The following discussion with a focus on the concept of home will show that this intermingling of fictive narrative with a meta-level of analysis is a defining characteristic of the novel.

A nearly obsessive quest for home dominates Ghana Must Go. Rosemary George defines this yearning for an authentic home as one of the characteristics of literature about migration (175). In “Colonialism, Imperialism, and Imagined Homes," Katrak generalizes about postcolonial narratives, where the concept of home "assumes a deromanticized and demystified harshness; these are societies deeply under stress where economic crises make daily survival a painful reality" (651). Thematically, the novel presents a portrait of a family devastated by separations and forced to search for their real home. At one point, Kweku sees himself and Fola as "[o]rphans, escap- 
ees, at large in world history, both hailing from countries last great in the eighteenth century-but prideful (braver, hopeful) and brimful and broke-so very desperately seeking home and adventure, finding both" (91). In addition, this novel is about death and rebirth in the sense that Kweku's dying becomes the central point that leads the narration into the past of each member of the Sai family and into the present level of narration with the family reunion in Accra, Ghana. Each family member becomes isolated in a hostile and indifferent world, forced to choose his or her destiny. Home is the opposite of the sense of homelessness that is both the state of being without a place to stay and without a country to belong to. In postmodern fashion, the novel is not linear or chronological. It is divided into three sections called "Gone," "Going," and "Go." The perspective shifts between the six members of the Sai family. There are many clues and hints about why characters in the novel act and react in a certain way, and the reader has to unfold the possible meanings layer by layer.

Fola is the prototypical exiled and displaced person. She suffers the traumatic murder of her father in the Nigerian war in 1966 and is sent to Accra, Ghana, by her father's partner at the law firm. There she finishes Ghana International School"seldom speaking, barely eating" (201). For years she clings to the few trinkets she could bring, and Nigeria becomes in her mind "nowhere she knew of, not home, not a place she could see, so not real" (201). "Different types of silence-imposing forces, self- and state-imposed," similar to the ones Katrak sees in the work of Rushdie (661), are at work here. The habit of seldom speaking leads to a silence and speechlessness that define her life. At one point in the novel, she lies next to her husband, "alive in the present and dead to the past" (197). She never tells him where she came from, he never talks about his own parents, and together they try to "uphold their shared right to stay silent" (197). It is precisely this act of not sharing, not talking, not telling about one's shame or loss or fear that is the cost of forced migration and a typical feature in immigrant novels. Fola, who is a mixture of her Yoruba father and white Scottish grandmother, is the refugee, one lucky enough to escape persecution but also one who is traumatized by the bloodshed and unrest in her country of origin. Nigeria is the nightmare of her past and at the same time the place where she spent a happy childhood. She can never be that carefree child again, and her growing up in another country and family makes it hard for her to understand what home really is. It is not the act of leaving itself but the loss of a sense of home and belonging, the many questions left unanswered and unexplained, that lead to devastating and long-lasting effects. Rosemary George writes about the migrant's "recognition of the inauthenticity or the created aura of all homes" (175). Fola's authentic home is not simply a geographical place; it is the place of the past that she cannot revisit; it is the father and the feeling of being protected that she has lost; it is her having to grow up in a hostile surrounding that counts.

Fola then leaves Accra, Ghana, but her second leaving is different. She goes for educational purposes; she does not have to leave home again because she has already been made homeless, heimatlos to use the German word. She becomes an immigrant 
to the United States. Fola attends Lincoln University, Pennsylvania, where Kwame Nkrumah, Ghana's first prime minister and president, also received his education. She stays in the United States for the next thirty years or so before she inherits a house in Accra and returns to live there. As Selasi points out in an interview, there is a lot of movement in the novel, but mostly, it is an initial movement for education followed by a prolonged period of staying in that country (Furlonge 535).

Kweku was born in a hut in Kokrobité, Ghana, and grows up without a father, who left his family. His beloved younger sister Ekua dies at the age of 11 of treatable tuberculosis at a time when the loss of an African child was considered to be "irrelevant" (27). Kweku refuses to think about this later: "He had no need for remembering, as if the details were remarkable, as if anyone would forget it all happened if he did. It would happen to someone else, a million and one someone elses: the same senseless loss, the same tearless hurts. This was one perk of growing up poor in the tropics" (28). In this passage, Kweku illustrates Judith Butler's question in Precarious Life about who counts as human and what "makes for a grievable life" (20). Kweku is presented as typical rather than exceptional, a participant in a larger and global experience in which no one cares that poor children die in great numbers. Much later, his son Kehinde explains to his youngest sister their parents' feelings of loss and estrangement and their never taking them to visit Africa: "They were hurt. ... Their countries hurt them" (240). Kweku is saved, so to speak, because he receives a scholarship to Lincoln University due to his great intelligence. There is only one visit home when his mother is dying. Despite his feeling of being estranged from his country of origin, he returns to Accra, perhaps as a kind of self-punishment, when Fola refuses to take him back in after his abandonment.

The moment when Kweku dies is described at great length and in detail. Kweku's dominant thought before his death is his realization that his life might be "all wrapped in meaninglessness" (20) and "that he's gotten it wrong" (20). He is the gifted student who was given a chance to get his education in the United States; he marries, fathers four children, and becomes a successful surgeon. The family lives in a poor house first and then in their colonial house in Boston, where he works at Beth Israel Hospital. His wife, Fola, sacrifices her career for his success and gives up her dreams of law school because "[o]ne dream's enough for the both of us" (73). They are the model immigrant family: Kweku provides the family income, Fola becomes the admired homemaker, and their children receive outstanding grades at school. When everything goes wrong, Kweku has little to fall back on. He is charged with ill treatment of a member of one of Boston's prominent families and is discharged following a medical lawsuit. "Then the machine turned against him, charged, swallowed him whole, mashed him up, and spat him out of some spout in the back" (69). He is even dragged out of the hospital with his son Kehinde watching the disgraceful incident. He has not told Fola about this problem although there is nearly a year between the operation and his dismissal. After this incident, he leaves the family suddenly and without warning. The year is 1993; Olu is about 18, Taiwo and Kehinde 14, and Sadie about 4 years old. 
Kweku becomes the tragic victim of a system that looks for a scapegoat when something goes wrong. He had protested against the operation on the seventy-sevenyear-old chain smoker with a ruptured appendix and a blood infection, but the hospital had promised to have the operation done by its best surgeon. When Kweku hears the hypocritical "II am afraid we have to let you go' " (72) in the plush uppermost hospital room, his world falls apart. At this decisive moment in his life he thinks of the family, that he failed them, and that he has nowhere to go (76). He is exhausted due to his relentless striving for excellence and the burdens of being responsible for a family. In the terms of Greek tragedy, his downfall is caused by a character weakness, a combination of false pride and cowardice. It is Arthur Miller's tragedy of the common man: "The flaw, or crack in the character, is really nothing-and need be nothing, but his inherent unwillingness to remain passive in the face of what he conceives to be a challenge to his dignity, his image of his rightful status. Only the passive, only those who accept their lot without active retaliation, are 'flawless' " (Miller). In a novel that is so full of allusions to literature, this particular idea of tragedy makes a lot of sense. We need to pity, the message goes, a man who has tried so hard and fails in such a tragic way. Kweku maintains his dignity by fighting against the wrongful dismissal. He does not give in but he is given up on, loses any chance of appeal, and drives away without letting anyone know about his reasons.

One can understand why Kweku becomes a victim of the system, but it is infinitely more difficult to account for his leaving a wife and four young children. There is a postcolonial message in the novel that explains the migrants' loss of home (nation and culture) because of the political effects of the African states after colonial rule. There are repeated references to their joyless colonial house in Brookline and detailed descriptions of his house built in Accra, a compound around a courtyard in a classically Ghanaian structure rather than a modern colonial mansion (23-24). Kweku is described as attempting and failing to cross the "bridge" "between worlds" (52). Shortly before he dies, Kweku remembers seeing the young Taiwo as "a modern thing entirely and a product of there, North America, snow, cow products, thoughts of the future," while he associates his mother with "an ancient thing, a product of here, hut, heat, raffia, West Africa, the perpetual past” (52). In particular, these passages where the discursive voice dominates over the narrative voice are not entirely convincing because the Sai family's disintegration after Kweku's leaving is not only a result of the immigrant status of the parents but a result of the shame that Taiwo recognizes later when she says shortly after his death: "That one never feels home who feels shame, never will" (273). The outward look of a house, the details of interior decoration, and the descriptions of rooms can only hint at but not fully explain the feelings of loss and shame.

A different explanation comes from Olu's future father-in-law, a Chinese American mathematician at MIT, who voices the common notion of Africans being a model minority because they are especially ambitious for themselves and their children to do well in higher education. At the same time, Dr. Wei expresses an old prejudice 
about people of African origin: "No respect for the family. The fathers don't honor their children or wives" (120). This hurts most because it is not only the utterance of a stereotypical notion of the African man, but because it is partly true. Kweku did leave his family; there is no excuse or denying the devastating results. But he left because he respected his family and because he did not want them to witness his failure. Olu understands this and answers back: "I'm just like my father. I'm proud to be like him" (120).

After failing to establish contact with his family some weeks after his abrupt leaving, Kweku and Fola divorce, Kweku returns to Accra, works as a surgeon, remarries, and builds a house. This return can be interpreted more as a self-punishment than as the homecoming of the successful emigrant. The awareness that he is about to die of a heart attack at the age of 58 leads him to remember and regret the past. His death calls the family together in a ceremony of hope and forgiveness. Both Kweku's failure in the United States and his subsequent return to Africa should be placed, as Gogol suggests about a different set of novels, into the "larger tradition of postcolonial writing" (xii). One characteristic is the reversal of "the heart of darkness narrative, where rather than Europeans or North Americans going to Africa to find themselves, an African character travels to the heart of the West, only to find darkness there" (xii). Similar to Adichie's novel Americanah, which Gogol uses as her main reference, Ghana Must Go also "challenges the conventions of the typical immigrant novel, where no alternative to life in America is entertained" (xii). Although the terrible traumas that Fola and Kweku of the first generation and Taiwo and Kehinde of the second generation carry with them originate in Africa, the novel still-similar to Adichie's Americanah-challenges "the association of Africa as trauma” (xiv) because its most climactic scene of healing and reunion is set in Accra.

When Olu hears about the death of his father in Ghana, he starts to cry and thinks about the distance between him and his father: "[H]e'll be miles and oceans and time zones away (and other kinds of distances that are harder to cover, like heartbreak and anger and calcified grief and those questions left too long unasked or unanswered and generations of father-son silences and shame)" (6). The weight of this sentence is carried between parentheses: The distance between father and son is geographical, no doubt, but the greater distance is that of grief and anger about the lack of communication between this particular father and his children that transcends borders and boundaries. As I said earlier, geography is the starting point, emigration and immigration are part of the problem, but the real distance is personal.

$\mathrm{Olu}$ is the brain of the younger generation; following in his father's footsteps, he becomes a successful doctor. He is the only one of the siblings who visits his father in Accra. On the day of his Yale graduation, he flies to Africa to find him. All along he had toured his friends' homes "aching with longing, for lineage, for a sense of having descended from faces in frames” (251). In the United States, looking for his father, he had always tried to spot him in a crowd: "He could always pick out Kweku in an instant by the color" (247) because no other father he knew had the same skin color. 
When Olu arrives in Accra, he is more than puzzled: "they were all the same color, more or less, all the fathers, his own blended in, indiscrete, of a piece" (247). When he meets his father, he is-somewhat naively-disappointed about his poor housing and the look of defeat on Kweku's face. Olu notices an air of homelessness around Kweku and pities him for being "cut off from the family" (253) and for his living in "a prison of his own making, in exile" (253). He is shocked that his father is "defeated, and willing to accept the defeat, not resisting, not objecting, as if somewhere inside him lived someone who felt quite at home in this place" (253). When Kweku tells him that this is what he comes from (253), Olu cannot understand that he is talking about his poor beginnings. Olu can only interpret and understand his father's defeat as a result of his leaving the family and the family's home in the United States. For him Accra is "exile," the place where the father is forced to return and where he is to start again from scratch. Olu is only able to move on after he has seen the hut where Kweku was born and realizes that his own fate is different. He comes to understand that this was the best his father could do and that he himself could do better. He tells his wife Ling about the visit: "He was that man. He was that stereotype. The African dad who walks out on his kids. The way that I'd always hoped no one would see us" (305). Only by talking to his wife does Olu finally understand the extent of Kweku's striving and failure: "The man came from nothing; he struggled, I know. I want to be proud of him. Of all he accomplished. I know he accomplished so much. But I can't. I hate him for living in that dirty apartment. I hate him for being that African man. I hate him for hurting my mother, for leaving, for dying, I hate him for dying alone” (306). Olu, who has no children with Ling and lives in a rather sterile apartment, needs the family reunion after his father's death so that he can move on and build a home of his own.

The twins Taiwo and Kehinde fare worst after Kweku's leaving. Jane Bryce names the use of twins a defining characteristic of and predominant trope in the narratives of the recent generation of female writers who come out of Africa (Akachi Ezeigbo, Chimamanda Ngozi Adichie, Sefi Atta, Unoma Azuah, Helen Oyeyemi, Diana Evans). The motif of the twins, doppelgangers, abiku (the child who appears and disappears) and ibeji (the Yoruba twin statues whereby a dead twin is placated), Bryce argues, is "complicated further by the motifs of migration, displacement, and metissage" (63). The intertextual references in Selasi's novel are multiple, and one of them is her naming one of the twins Kehinde, which is the name of the main female protagonist in Buchi Emecheta's novel Kehinde. Fola sends Taiwo and Kehinde to live with her half-brother in Lagos because she is afraid that she cannot take care of them and provide them with the education they deserve. This is the most difficult part of the novel to understand. Fola must have known how much her half-brother hated her. It is hard to understand why she sends the adolescents, who had just been confronted with the absence of their beloved father, to live a full continent away without her protection. The twins live through traumatic experiences that they do not fully understand and that will fundamentally destroy their innocence and self-esteem. Uncle Femi, Fola's half-brother, has always hated Fola because she was the light-colored 
princess daughter of his father's first half-white wife, while he was only the black son. After staying there for some time, the twins are sexually abused and forced to commit sexual acts upon each other. They are made to pay for the sins of their fathers and mothers, and they learn that their identities are not personal and individual but collective. They are eventually saved and sent home by Fola's friend who recognizes them: "Just saw them there huddled up, children among adults, and knew who they were and that something was wrong; they were both wearing makeup and spoke as if drugged" (237). They return "too skinny, not speaking” (238) and when Fola questions them about their experience, they refuse to speak about it.

Uncle Femi associates Taiwo with the "pale, hateful beauty" of his father's first wife. Taiwo recognizes that the face of her grandmother in the picture on the wall of Uncle Femi's living room is her own. She now knows that her beauty, her skin color, and her body are the inheritance of that grandmother, but she cannot be happy about this because this likeness has led to her abuse. After this traumatic event, Taiwo blames Fola for sending her away and her father for leaving her alone. She later begins an affair with the dean of her university where she is a successful law student, and when this is made public, she has to leave in disgrace and needs psychotherapy for years. Her life is insomnia, emptiness, sorrow, and grief.

Kehinde has always been able to speak with Taiwo without using words. He can hear her voice in his head and knows what she is trying to say even without her actually saying it. After their stay in Lagos, Kehinde cannot stop thinking that their abuse was his fault because he was not strong enough to protect her (208). He becomes a famous artist but stops speaking to Taiwo after she has told him about the affair with the dean. He embraces her too tightly (177-178) and Taiwo, remembering what happened in Lagos, feels left alone and unprotected and cannot speak to him for the next few years, even when she learns that he attempted suicide. Kehinde paints Taiwo's face with an obsession that is reminiscent of their earlier closeness, but he cannot build up a relationship of his own with another woman.

The youngest daughter Sadie learns about her father's death at her twentiethbirthday party. When he left the family, she was too young to remember him properly and, therefore, grew up very close to her mother. In Trailing Clouds, David Cowart mentions eating disorders and the missing parent as generic constituents of immigrant fiction (7-8). Sadie suffers from bulimia because she has always felt left out in her family. Taiwo hardly ever talks to her, Kehinde is in London, and Olu is too old for her to establish a relationship. She thinks of her family as "weightless," "a family without gravity," "completely unbound," with no roots and "no living grandparents, no history" (146-147). She is also interested in her female roommate and does not quite know how to cope with her intense liking for another girl. Sadie is an extremely gifted person with a photographic memory, but she does not yet know who she is. For Sadie the trip to Accra for her father's burial is essential. She is recognized by Kweku's half-sister as a re-incarnation of her Aunt Ekua, the one who died as a child. Sadie hears the African drums and starts to dance "as if she'd been born doing tra- 
ditional Ga dance" (268). Something in her falls into place, "the stranger inside her that knows what to do" (269). She realizes that she felt left out and lonely because she missed this family background. Now that she knows where she comes from, she is confident about her future.

When the four siblings arrive in Accra, Fola welcomes them to their new home. They take care of funeral arrangements and seek reconciliation with their estranged siblings and forgiveness for their parents. Taiwo finally tells her mother what happened back then, Olu makes his peace with his father and thinks about a family of his own, Kehinde reconciles with Taiwo, and Sadie finds her place in the world. It is significant that they meet in the father's country of origin and that only this journey back makes it possible for them to move forward. When Fola imagines the conversation with Kweku in which she said they were immigrants and that immigrants left, she realizes that while they had learned how to cope with the leaving, the next generation will have to learn to stay (317). At dinner on Christmas Eve, they are reunited in peace.

"Novels of postcolonial expatriates and exiles," Katrak writes, "represent the conflictual realities of geography, location, and language, the myth and reality of a return 'home,' the search for intellectual spaces with their 'chosen' exile and/or expatriate 'homes' " (654). In migration, Paul White adds, "the levels of ambivalence, of plurality, of shifting identities and interpretations are perhaps greater than in many other aspects of life" (15). In Ghana Must Go, these levels are heightened to an alarming degree because the protagonists undergo and suffer from migration and adolescence at the same time: Fola and Kweku leave their home countries at an early age, and their children are made to suffer from the abandonment of the father and subsequent relocations because the father does not withstand the pressure of success in the new surroundings and because the mother cannot explain to them their origin. Growing up and migrating are interlinked experiences in which Selasi herself, the self-conscious author, is engaged: She offers a discourse and tells a story at the same time. In an interview, Selasi describes her voice as "wondering” and "wandering”: "It's wondering what is true and it's wandering through sound and form as one might wade through a river to get there, to find that truth" (Furlonge 533). She writes about the break-up and reunion of a family and explains the individual family members' trials and triumphs to the reader with the ulterior motive of making one family's story stand in for many others, or, to use the perspective of Kweku: "To have somehow unhooked his little story from the larger ones, the stories of Country and of Poverty and of War that had swallowed up the stories of the people around him and spat them up faceless, nameless Villages, cogs” (Ghana 91).

Selasi sees herself as "lost in transnation" ("Bye-Bye” 530) and balances her own background with a discourse and a narrative on nation, migration, and home. In her recent James Walston Memorial Lecture in Rome on April 22, 2016, a stunning and eloquent Selasi wonders why people introduce her as a writer "from Ghana and Nigeria" or from "England and the United States" For her the singular country is a fiction because, she says, "I am a local, I am multilocal." Instead of asking her, "Where are 
you from?” people should ask instead, “Where are you a local?” In terms of rituals, relationships, and restrictions, the three "R's" that she finds essential, you are local, she explains, where you perform your rituals and maintain your relationships. The restrictions you are subjected to make it possible for you to live at a certain place or in a certain country and often prevent you from living in the locality where you had your rituals as a child. As a successful writer and mature person, she now prefers being introduced as "a human being like everybody here," not as "a citizen of the world, but a citizen of worlds," and as a "local of New York, Rome, and Accra” ("Migration”).

\section{Works Cited}

Boehmer, Elleke. Colonial and Postcolonial Literature: Migrant Metaphors. Oxford UP, 1995.

Braidotti, Rosi. Nomadic Theory: The Portable Rosi Braidotti. Columbia UP, 2011.

Bryce, Jane. “ 'Half and Half Children': Third-Generation Women Writers and the New Nigerian

Novel." Research in African Literatures, vol. 39, no. 2, 2008, pp. 49-67.

Butler, Judith. Precarious Life: The Powers of Mourning and Violence. Verso, 2004.

Chambers, Iain. Migrancy, Culture, Identity. Routledge, 1994.

Cohen, Stefanie. "Growing Up With a Panther Mom." Wall Street Journal, 28 Feb. 2013, www.wsj. com/articles/SB10001424127887323384604578328694096820534. Accessed 17 Apr. 2014.

Cowart, David. Trailing Clouds: Immigrant Fiction in Contemporary America. Cornell UP, 2006.

"Family Matters: How Novelist Taiye Selasi Came to Terms with Her Very Modern Family." London Evening Standard, 5 Apr. 2013, www.standard.co.uk/lifestyle/esmagazine/ family-mattershow-novelist-taiye-selasi-came-to-terms-with-her-very-modern-family-8560426.html. Accessed 17 Apr. 2014.

Furlonge, Nicole Brittingham. “An Interview with Taiye Selasi." Callaloo, vol. 36, no. 3, 2013, pp. 531-539.

George, Rosemary Marangoly. The Politics of Home: Postcolonial Relocations and Twentieth-Century Fiction. Cambridge UP, 1996.

Gogol, Yogila. Introduction. Africa and the Black Atlantic, special issue of Research in African Literatures, vol. 45, no. 3, 2014, pp. v-xxv.

Katrak, Ketu H. "Colonialism, Imperialism, and Imagined Homes." The Columbia History of the American Novel, edited by Emory Elliott, Columbia UP, 1991, pp. 649-678.

Mayer, Ruth. "Postcolonial/Transcultural/Transnational: American Studies, American Literature, and the World." American Studies Today: New Research Agenda, edited by Winfried Fluck et al., Universitätsverlag C. Winter, 2014, pp. 139-155.

Miller, Arthur. "Tragedy and the Common Man." The Theater Essays of Arthur Miller. 1949. Viking P, 1978, pp. 3-7.

Paul, Heike. Mapping Migration: Women's Writing and the American Immigrant Experience from the 1950s to the 1990s. Universitätsverlag C. Winter, 1999.

Sarup, Madan. Identity, Culture and the Postmodern World. Edited by Tasneem Raja, with a foreword by Peter Brooker, U of Georgia P, 1996.

Selasi, Taiye. "Bye-Bye Barbar." Callaloo, vol. 36, no. 3, 2013, pp. 528-530. Project MUSE, doi: 10.1353/cal.2013.0163. Accessed 17 Apr. 2014.

--.. Ghana Must Go. Viking, 2013. 
--.. "Migration: Identity and Nationality." James Walston Memorial Lecture, 22 Apr. 2016. www.aur. edu/blog/myevents/migration-identity-and-nationality-the-james-walston-memorial-lecture2016-by-taiye-selasi/. Accessed 23 Mar. 2017.

Singh, Amritjit, and Peter Schmidt, editors. Postcolonial Theory and the United States: Race, Ethnicity, and Literature. UP of Mississippi, 2000.

White, Paul. "Geography, Literature and Migration." Writing Across Worlds: Literature and Migration, edited by Russell King et al., Routledge, 1995. pp. 1-19. 